\title{
INHIBITING FACTORS TO TAX REVENUE GENERATION IN CROSS RIVER STATE, NIGERIA
}

\author{
BASIL RICHARD EJA, SUNDAY EGBE IDAKA AND OGAR-ABANG JOHN
}

(Received 23 January 2018; Revision Accepted 7 June 2018)

\begin{abstract}
This study examined the inhibiting factors to tax revenue generation in Cross River State, Nigeria. The specific objectives were to examine the effect of tax evasion and avoidance, lack of infrastructural facilities and experienced personnel on tax revenue generation in Cross River State. To achieve these objectives, a well structure questionnaire was development and administered on 169 sampled staff of Cross River State board of internal revenue. Out of these questionnaires 164 were duly completed and returned. These responses were coded and used for analyses with the help of the SPSS software The cross sectional survey design was adopted and the ordinary least squared multiple regression technique was used to analyze the data. From the analyses it was discovered that there is a negative correlation and insignificant relationship between lack of infrastructural facilities and government tax revenue in Cross River State; also, there is a negative and significant relationship between tax evasion and avoidance and government tax revenue in Cross River State, Nigeria and lastly, there is a positive and significant relationship between experienced personnel and government tax revenue in Cross River State, Nigeria. Based on these finding the study recommends that government should encourage tax payers' morale through the provision of quality infrastructural facilities and other incentives to enhance its revenue generation. Also, Strategies to reduce tax evasion and avoidance should be formulated by strengthening the policy framework and operational guidelines of the Cross River State internal revenue service and adopting an evidence base government spending. Lastly, Cross River State internal revenue service should embark on adequate staff training and development on new methods of enhancing tax compliance within the state.
\end{abstract}

KEYWORDS: Tax Revenue Compliance, Tax Evasion and Avoidance

JEL Classification: C12, C13, C42, E62, H26

\section{INTRODUCTION}

It is a well established fact that tax revenue constitutes a major source of income for government in many countries both developed and developing. As categorically observed by Worlu and Emeka (2012), tax revenue utilization is a basis for supporting developmental activities in less developed economics Nigeria inclusive. In a state like Cross River that is still struggling to remain afloat given the loss of her oil wells, revenue generated from taxation is even more important. For developmental projects such as provision of infrastructure like stable water supply, good roads, stable power etc. tax revenue is the major source of funding (Ojochogwu and Ojeka, 2012).

However, it has been difficult to optimize tax revenue collection in Nigeria in general and Cross River State in particular due to several inhibiting factors such as tax evasions, corruption, lack of infrastructural facilities,

Basil Richard Eja, Department of Banking and Finance, University of Calabar, Calabar, Nigeria.

Sunday Egbe Idaka, Department of Accounting, University of Calabar, Calabar, Nigeria.

Ogar-Abang John, Department of Accounting, University of Calabar, Calabar, Nigeria.

(C) 2018 Bachudo Science Co. Ltd. This work is licensed under Creative Commons Attribution 4.0 International license. 
inexperienced personnel etc. As noted by Simser (2008), tax evasion occurs when people or organizations deliberately refuse to abide by their tons responsibility. It is an issue that is perceived to be as longstanding as taxation itself. A serious challenges facing tax administration in Cross River State and hindering tax revenue performance is tax noncompliance. According to Tijani and Ogundeji (2013), widespread tax evasion reflected in persistent public resistance to pay is seen as an important part of the issues of raising revenue in any part of the world. As suggested in taxation literature, building administrative capacity in the tax in order to enhance revenue collection is one of the measures which may be used to address the non-compliance problem. The amount of revenue linkage or loss resulting from tax evasion is potentially enormous and devastating in any economy (Devos, 2008).

Another inhibiting factor to tax revenue generation in Nigeria is lack of experienced personnel. The enforcement machinery of the Nigeria tax laws, Cross River State in specific seem so weak that tax payers go against them effortlessly (Tijani and Ogundeji, 2013). The personnel responsible for tax policies administration and implementation seem illequipped as they often do not seem to possess the required or need skills to carry out their duties effectively and efficiently. The resultant outcome is revenue linkage unproductiveness.

As noted by Umar, Derashid and Ibrahim (2017), tax to Gross Domestic Product (GDP) ratio is a measure of the amount of tax revenue countries are expected to raise. Globally, it is adopted as a standard and acceptable benchmark for assessing how well governments are raising tax revenues to finance their activities. World bodies in their global monitoring of government fiscal activities officially adopt this position. Based on the expert advice of Kaldor (1963), the international monetary fund (IMF) recommends $15 \%$ of GDP as the minimum benchmark on which countries should raise tax revenue. Kaldor's position is that countries which fall below this benchmark are at fiscal risk. Globally, the tax ratio to GDP is such that the more developed economics or countries raise an average of $35 \%$ of their GDPs as tax revenue while developing countries or sub-saharan African countries raise an average of $17 \%$ (OECD, 2013). The wide disparity between developed and developing countries is an issue of worry to global policy makers and tax compliance researchers (Besley and Person,
2014). IMF (2015) maintains tax noncompliance is one of the major factors responsible for low tax revenue generation in developing countries like Nigeria.

The zeal to resolve the problem of low tax revenue generation in order to boast development in Cross River State has led to the formulation of several reform policies in order to restructure the state's tax system for improved performance. However, reports have shown that not much have been achieved. The thrust of this paper therefore is to examine the inhibiting factor to tax revenue generation in Cross River State.

\subsection{Objectives of the study}

The aim of this study is to evaluate the inhibiting factors to tax revenue generation in Cross River State, Nigeria. In order to accomplish this objective, three specific objectives were formulated thus:

1. To examine the effect of poor infrastructural facilities on tax revenue generation in Cross River State, Nigeria.

2. To evaluate the impact of tax evasion and avoidance on tax revenue generation in Cross River State, Nigeria and

3. To determine the effect of experience personnel on tax revenue generation in Cross River State, Nigeria.

\section{$1.3 \quad$ Research hypotheses}

In order to accomplish these objectives, three research hypotheses were formulated thus:

$\mathrm{Ho}_{1}$ : There is no significant effect of poor infrastructural facilities on tax revenue generation in Cross River State, Nigeria.

$\mathrm{Ho}_{2}$ : There is no significant impact of tax evasion and avoidance on tax revenue generation in Cross River State, Nigeria.

$\mathrm{Ho}_{3}$ : There is no significant impact of experience personnel on tax revenue generation in Cross River State, Nigeria.

\subsection{Review of empirical literature}

As stated by Umar, Derashid \& Ibrahim (2017), there is a unanimous agreement among tax researchers scholar and international agencies that noncompliance with tax provisions is a huge challenge currently hampering tax revenue mobilization efforts especially among developing economics. This position is supported by data from existing research which points to a large scale non-compliance by taxpayers in developing countries. For instance, Kangave, Nakato, Waiswa and Zzimbe (2016) investigated 
60 top lawyers (commercial law firms) in Uganda and discover that only 12 paid income tax in 2012 and only 13 paid in 2013 . This constitutes about 21 percent compliance leaving about 79 percent noncompliance with tax provisions.

Okonjo-Iweala (2014) asserted that 75 percent of registered firms in Nigeria are not in the tax system. That even among the 25 percent that are registered, 65 percent had not filed any tax return for two years. Fjeldstad and Heggstad (2011) investigated tax compliance in Tanzania. The study revealed that out of the 45 million people those registered for tax purpose are only 400,000 . In 2010 , only 400 registered tax payers contributed 80 percent of the total tax revenue while an overwhelming majority evaded their tax obligations.

Ojochogwu and Ojeka (2012) examined factors that affect tax compliance among small and medium enterprises (SMEs) in North central Nigeria. The study was conducted using SMEs in Zaria, North-Central Nigeria to evaluate and rank the factors that encourage non-compliance with tax obligations by SMEs. It was found that high tax rate and complex filing procedures are the most crucial factors causing noncompliance of SMEs. Other factors like multiple taxation and lack of proper enlightenment affect tax compliance among the SMEs surveyed only to a larger extent. It was recommended that SMEs should be levied lower percentages of taxes to allow enough funds for business development and better chances of survival in a competitive market.

Ifere and Eko (2014) investigated tax innovation, administration and revenue generation in Nigeria: Case of Cross River State. The study was set out to investigate efficiency and effectiveness in the administration of tax in Nigeria using Cross River State as a case study. The methodology adopted was qualitative techniques using questionnaire to survey the three senatorial districts in the state. The central limit theory was adopted as analytical technique. Result showed a significant degree of inefficiency in the administration of taxes leading to low revenue generation. It was recommended that periodic review and update of tax policy will bring innovation and effectiveness in the administration of taxes. Also proper appropriation of tax revenue will drive development in needed infrastructural and social services.

Tijani and Ogundeji (2013) examined professional perspective of tax evasion: Some evidence from Nigeria. The study was carried out through a structured survey directed at tax professionals. This information was collected in order to explain the determinant of tax evasion. The result show that tax evasion in Nigeria is largely influenced by complexity in the tax structure, perceived financial and economic benefits associated with tax evasion, and lack of trust in government over financial resource utilization. The outcome suggest that there should be adequate implementation of appropriates recommendations made in the study towards enhancing a better tax policy and improved tax administration in the country.

Mansor and Gurama (2016) examined factors influencing tax evasion in Gombe state Nigeria. The study assessed the factors that influenced tax evasion in Gombe Sate (a state in Nigeria). The study was conducted through a survey research design. A questionnaire was used to gather primary data from 303 randomly selected public and private sector personal tax payers in Gombe. The result of the analysis show that tax system, income level and education level have significant positive relationship with tax evasion. On the other hand, tax rate and corruption have positive but insignificant relationship with tax evasion. The study recommends that necessary measures should be taken by the tax authority to improve accountability, transparency and management of revenue collection to reduce tax evasion.

Umar, Derashid and Ibrahim (2017) asserted the challenges of tax revenue generation in developing countries; adopting the carrot and stick approach. The study identifies tax noncompliance as a key factor for the current underperformance of tax revenue in developing countries. The study advocates for the carrot and stick model in tackling the challenges of tax compliance in developing countries. It argues that an optimal mix of the carrot and stick factors will go a long way in tackling the tax revenue challenges of developing countries. Citizens engagement in tax policy formulation and tax service quality are the carrot factors that encourage high compliance in tax payment while, sanction of tax defaulters in line with extant law is the stick factor.

Although the literature on factors that hinders effective tax revenue mobilization in vast, majority of the studies lay most emphasis on tax evasion. The main different between this current study and prior inhibiting factors to tax revenue generation is the inclusion of infrastructural facilities as a factor that hinders tax revenue mobilization. In addition, previous inhibiting factors to tax revenue generation study in Nigeria 
were established in largely populated state with advance sources of revenue generation development of social amenities and infrastructure. This study has chosen Cross River State with the objective of studying the problem in a smaller populated state in a different region with growing potentials and less developed source of revenue generation.

\subsection{Theoretical framework}

Many theories have been propounded by scholars with the view of encouraging the tax payers on the need for tax and why tax payer show nonchalant attitude towards the payment of tax to the government which has resulted in few people complying in their civil responsibilities. The various theories that have been propounded by different scholars are: the planning behavior theory, benefit received theory, ability to pay theory and diffusion theory.

Planning behavior theory: The planning process of the tax officials and the altitude of the payers as regard to tax aversion and avoidance and poor compliance is the main crux of this theory. The attitude of tax officials in ensuring effective administration that will boost the individual tax payers to have the will of seeing tax as an instrument for economic development is a motivational factor that will ensure effective and efficient administration of the tax system which will in turn enhance revenue generation (Ajzen, 1991). The strategies adopted in the tax system is a motivational factor that will propel the tax payers to comply willingly as behaviours differs from one tax payer to another and even the intention of the tax payers to choose either to perform their civil duties also differs among the tax payers.

Benefit received theory: The main crux of this theory is aim at the benefit the tax payers received for parting a portion of their income to the government through taxation. The rationale about the benefit theory is to ensure that the more revenues are generated through taxation, the more benefit the citizens should receive as a compensation for carrying out their civil responsibilities. Looking at this relationship between the tax payers and the government, it is a contractual relationship that requires that when one party fulfills its own obligations, the other should also reciprocate in the same way. The benefit theory has a lacuna because it is hard for the government to measure exactly the benefit that individual tax payers derived in order to know the amount that each tax payer will be levy to match the benefit he/she is receiving. It is impractical to adopt the benefit received theory since the objective of taxation is to ensure redistribution of income by imposing high tax to the rich than the poor. The application will negate the objective because the poor might end up paying high tax than the rich since most of the government expenditure is aim at ameliorating the lives of the plebeians in the society.

Ability to pay theory: The tax payers in which the tax is gotten from done have the same level of income. As such, it is expected based on tire ability to pay theory that each tax payer should be levy the amount he/she will pay as tax with regards to their income. Those with high incomes should be tax high and those with tow income should be tax low based on the income they received. In practice, effective administration with a well articulated process will encourage voluntary compliance by the tax payers because such process is to ensure that tax payers are not over-burden in terms of the amount to pay as tax which is a function of their incomes. This theory holds that tax payers carry out their civil responsibilities because they are buoyant to do so and not a kind of commercial dealings between the tax payers and the government which oblige both parties to fulfill all conditions in the terms of agreement, rather the ability to pay is to ensure equity and justice in the amount tax that an individual will pay as tax (Musgrave \& Musgrave, 2004; Bhartia, 2010, Jhingan, 2012, and Appah, 2011).

Diffusion theory of taxation: The diffusion theory of taxation is anchored on the assumption that in a stable or perfect market condition, the tax that is levied will automatically diffused or absorbed throughout the environment. But in real life situation, the tax levied on the tax payers does not diffused automatically. Within the community because the tax official still need to ensure that they adopt effective strategies to inform the tax payers about the tax that have been imposed on them and the need for compliance. Mansfield (1961), an advocate of this theory hold that when tax is levied of automatically passes to the users of commodity and the burden is share between the manufactured and the consumers. The diffusion theory has always been criticized because it is not all taxes that diffused automatically, and as such, the need for effective administration is a panacea to ensure compliance in order to reduce the incidence of tax aversion and avoidance. The quantum of revenue generated is a function of how effective the administration is because taxes like: income tax, toil tax and inheritance tax does 
not absorbed rather. The individual or the tax payer bear the burden alone.

\subsection{Research methodology}

This study adopts the cross sectional survey research design which is more appropriate to gather information through questionnaires and meant to be measured at the same time. The population of the study is made up of 280 staff of the Cross River State Internal revenue service and Agency has 13 departments. The random sampling techniques was used and the sample size utilized is 169 samples which was determined using Taro Yamane method.

The data gathered for this study were summarized and tabulated using tables and percentages. The data were analyzed using the ordinary least square multiple regression technique. The ordinary least square technique is a best linear unbiased estimated unlike other estimators, hence it application in this study. Also, since the study seeks to establish the inhibiting factors to tax revenue generation in Cross River State, regression analysis will be the appropriate analytical technique because it tests cause and effect relationship(s) between two or more variables. The analysis will be carried out with the aid of statistical package for social science (SPSS) software version 20.

\subsection{Model specification}

The ordinary least square multiple regression model was used to test the effect of lack infrastructures facilities, tax evasion and avoidance, experience personal on revenue generation in Cross River State. The functional relationship predicted by this theory could be expressed thus:

REG $=f(P I S F$, TAXE, EXP)

The ordinary least square multiple regression model was given as:

REG $=\beta o+\beta_{1}$ PISF $+\beta_{2}$ TAXE $+\beta_{3}$ EXP $+e_{t} \ldots .$.

Where

$\beta o=$ Regression constant

$\beta_{1}, \beta_{2} \& \beta_{3}=$ Regression Parameters

REG $=$ Revenue Generation

PISF $\quad=$ Poor infrastructural facilities

TAXE $=$ Tax Evasion and Avoidance

EXP $=$ Experience Personnel

$\mathrm{e}_{\mathrm{t}} \quad=\quad$ Stochastic error term

\subsection{DATA ANALYSES AND DISCUSSION OF FINDINGS}

\subsection{Data analysis}

The questionnaire was coded and the data were keyed into the SPSS software and computed with the ordinary least squared technique. The extract of the result is presented in table 4.1 below:

Table 1: Regression result Dependent variable: REG

\begin{tabular}{lllll}
\hline Variable & Coefficient & Std Error & t-stat & Prob. \\
& & & & \\
\hline C & 5.358 & 0.831 & 6.445 & 0.000 \\
PISF & -0.038 & 0.074 & -0.510 & 0.614 \\
TAXE & -0.262 & 0.060 & -4.337 & 0.000 \\
EXP & 0.091 & 0.045 & 2.094 & 0.045 \\
$R^{2}$ & 0.864 & & & \\
$R^{2}$ (adj)- & 0.843 & & & \\
F-stat - & 39.811 & & & \\
\hline
\end{tabular}

Source: SPSS computation, 2017. 
From table 4.1, there is a negative relationship between lack of infrastructural facilities and revenue generation in Cross River State, Nigeria. This is as theoretically expected, a one percent increase in infrastructural facilities decay led to a 3.8 percent, decreases in revenue generation in Cross River State, Nigeria. Also there is a negative relationship between tax evasion and avoidance and revenue generation in Cross River State, Nigeria. This is as theoretically expected, a one percent increase in tax evasion and avoidance led to a 26.2 percent, decreases in revenue generation in Cross River State, Nigeria. Furthermore, table 4.1 showed a positive relationship between experienced personnel and revenue generation in Cross Rive State, Nigeria. This is as theoretically expected, a one percent increase in experience personnel led to a 9.1 percent, increases in revenue generation in Cross River State, Nigeria.

The goodness of fit of the model as indicated by the $R^{2}$ and adjusted $R^{2}$ values of 0.864 or 86.4 and 0.843 or 84,3 percent indicates that the model has a good fit. Specifically, the $R^{2}$ adjusted value of 84.3 percent indicates that the total variation in the observed behaviour of government revenue generation in Cross River State is jointly explained by the variations in the lack of infrastructural facilities, tax evasion and avoidance and experienced personnel up 84.3 percent, the remaining 15.7 percent is accounted for by the stochastic error term. The overall significance of the model was also tested using the ANOVA or f-statistics.

Here the high significance of the f-statistics value of 39.811 percent confirmed that the high explanatory power of the model did not occur by chance, it .actually confirmed that the model fits the data well.

The individual statistical significance of the parameters of the respective, independent variables was also tested. The result obtained showed that lack of infrastructural facilities was not statistically significant, since the probability value of its calculated t-statistics values of 0.510 was found to be greater than 5 percent. The result also the probability values of the calculated t-statistics of tax evasion and avoidance were less than 5 percent which means that tax evasion and avoidance have significant effect on government revenue generation in Cross River State, Nigeria.

\subsection{Test of Hypotheses}

\section{Hypothesis one}

Ho: There is no significant effect of lack of infrastructures facilities on revenue generation in Cross River State, Nigeria.

$\mathrm{H}_{1}$ : There is a significant effect of lack of infrastructures facilities on revenue generation in Cross River State, Nigeria.

\section{Decision rule:}

Accept Ho: If calculated $t$-statistics value < table t-statistics value.

Reject Ho: if calculated t-statistics value $>$ table tstatistics value.

From the regression result,

Calculated $t$-statistics value $=0.510$

Table $\mathrm{t}$-statistics value $=2.074$

Since the calculated t-statistics value of 0.510 is less than the table t-statistics value of 2.074 at 5 percent significant level, we reject the alternative hypothesis and accept the null hypothesis. It therefore means there is no significant effect of lack of infrastructures facilities on revenue generation in Cross River State, Nigeria.

\section{Hypothesis two}

Ho: $\quad$ There is no significant impact of tax evasion and avoidance on revenue generation in Cross River State, Nigeria

$\mathrm{Hi} \quad$ There is a significant impact of tax evasion and avoidance on revenue generation in Cross River State, Nigeria

\section{Decision Rule}

Accept Ho: if calculated t-statistics value $<$ table t-statistics value.

Reject Ho: if calculated t-statistics value > table tstatistics value.

From the regression result,

Calculated $\mathrm{t}$-statistics value $=4.337$

Table $\mathrm{t}$-statistics value $=2.074$

Since the calculated $t$-statistics value of 4.337isgreater than the table t-statistics value of 2.074 at 5 percent significant level, we reject the null hypothesis and accept the alternative hypothesis. It therefore means that there is a significant impact of tax evasion and avoidance 
on revenue generation in Cross River State, Nigeria.

\section{Hypothesis three}

Ho: There is no significant impact of experience personal on revenue generation in Cross River State, Nigeria.

$\mathrm{Hi}$ There is a significant impact of experience personal on revenue generation in Cross River State, Nigeria.

\section{Decision Rule}

Accept Ho: if calculated t-statistics value < table t-statistics value.'

Reject Ho: if calculated t-statistics value' > table t-statistics value.

From the regression result.

Calculated $\mathrm{t}$-statistics value $=2.094$ Table $\mathrm{t}$ statistics value $=2.074$

Since the calculated t-statistics value of 2.094 is greater than the table t-statistics value of 2.074 at 5 percent level of significance, we reject the null hypothesis and accept the alternative hypothesis. It therefore means that there is no significant impact of experience personal on revenue generation in Cross River State, Nigeria.

\subsection{Discussion of findings}

This study examined the impact of income tax administration in Cross River State on revenue generation using tax evasion and avoidance, experienced personnel and lack of infrastructural facilities as measures of tax administration. According to the findings of the above analysis, there is a negative and insignificant relationship between lack of infrastructural facilities and revenue generation in Cross River State, Nigeria. In other words, the infrastructural decay, the less the revenue generation capacity of Cross River State, Nigeria. This implies that tax payers will not want to pay tax, if they are not motivated through the provision of adequate and vibrant infrastructural facilities. This finding is supported-by Yahaya (2009) who studied the challenges of taxation in Nigeria using descriptive and inferential statistic. The study concluded that inadequate utilization of public funds by government for infrastructural development was a key a key factor responsible for reduced tax revenue generation in Kwara State.

The study further reveals that there is a negative arid significant relationship between tax evasion and avoidance and revenue generation in Cross River State, Nigeria. This implies that the higher the tax evasion and avoidance, the lower the revenue generation capacity of government. This is so because tax evaders and avoiders limit the revenue base of government. This reduces the total fund generated by the government and reduces spending.

This finding is in tandem with the findings of Timmon (2005) who held that tax evaders and avoiders reduces the revenue base of government and reduces the spending capacity of government.

Lastly, the study reveals, that there is a positive and significant relationship between experienced personnel and the revenue generation capacity of government. This implies that the higher the engagement of experience tax personnel the higher the revenue of government. When the government engages experienced tax policy, the issues of tax evasion and avoidance will be reduced thus resulting in an increase in government revenue base. 'This finding is in line with the finding of Ebeke and Ehrhart (2011) who discover that the key determinant of government revenue is the level of experienced personnel engaged by the government.

\subsection{SUMMARY OF $\quad$ FINDINGS, CONCLUSION AND RECOMMENDATION}

\subsection{Summary of finding}

This study examined the challenges to government tax revenue generation in Cross River State using lack of infrastructural facilities, tax evasion and avoidance and experience personnel as measured of the challenging factors. To achieve these objectives, the study administered questionnaire on 164 sampled respondents of the Cross River State Internal revenue service. The responses from the questionnaires were coded and key into the SPSS software to estimate the variables using the ordinary least square multiple regression technique. From the estimated result, the following major findings were made:

(i) There is a negative but insignificant relationship between lack of infrastructural facilities and government tax revenue in Cross River State, Nigeria.

(ii) There is a negative and significant relationship between tax evasion and avoidance and government tax revenue in Cross River State, Nigeria. 
iii) There is a positive and significant relationship between experienced personnel and government tax revenue in Cross River State, Nigeria

It is in view of this that this study concludes that the tax revenue generation capacity of banks is determined by the use of tax payers money infrastructural facilities, the rate of tax evasion and avoidance and the level of experienced personnel employed for tax administration.

\subsection{RECOMMENDATIONS}

Relaying on the above findings and recommendations, the study recommends that:

i) Government should encourage tax payers morale through the provision of quality infrastructural facilities and other incentives to enhance its revenue generation.

ii) Strategies to reduce tax evasion and avoidance should be formulated by strengthen the policy framework and operational guidelines of the Cross River State internal/revenue service and adopting an evidence base government spending. That is, government should spend tax revenue on public goods and productive ventures that will be of social and economic benefit to the tax payers. This will enhance high tax compliance.

iii) Cross River State internal revenue service should embark on adequate staff training and development on news methods of enhancing tax compliance within the state.

\section{REFERENCES}

Ajzen, I., 1991. The theory of planned behaviour. Journal of Organizational Behaviour and Human Decision Processes, 50, 179211.

Appah, E., 2011. Cooperate tax incentive: A tool for the economic growth and development of Nigeria. International Journal of Social Sciences, 3(2): 20- 27.

Bhartia, H. L., 2010. Public finance. New Delhi: Vikas publishing house PVT Ltd.

Besley, T. and Persson, T., 2014. Why do developing countries tax so little? Journal of Economics Perspectives, 28(4), 92120.

Devos, K., 2008. Tax evasion behaviour and demographic Factors: An Exploratory Study in Australia, Review Law Journal, 18(1), 1-43.

Ebeke, E. and Ehrhart, H., 2010. Tax revenue inability in sub-saharan Africa. Consequence and remedies Mimeo, CERDI, Auvergne University France.

Fjeldstad, O. H. and Heggstad, K. K., 2011. The ta systems in Mozambique, Tanzania and Zambia: Capacity and constraints. CMI Reports.

Ifere, E. O. and Eko E. O., 2014. Tax innovation, administration and revenue generation in Nigeria: A Case of Cross River State. International Journal of Economies and Management Engineering, 8, (5).

IMF., 2015. Current challenges in revenue mobilization: Improving tax compliance. International Monetary Fund, Washington.

Jhingan, M. I., 2012. Money, Banking, international trade and public finance. New Delhi: Vrinada publication.

Kaldor, N., 1963. Will underdeveloped countries learn to tax? Council on Foreign Relations: Foreign Affairs, JAN, 1963.

Kangave, J., Nakato, S., Waiswa, R. and Zzimbe, P. L., 2016. Boosting revenue collection through taxing high net worth individuals: The case of Uganda. ICTD Working paper No. 2541.

Mansfield, E., 1961. Technical charge and the rate of imitation. Econometrica, 4(25), 741-756.

Mansor, M. and Gurama, Z., 2016. Factors Influencing tax evasion in Gombe State Nigeria. The European proceedings of social and behavioural science.

Musgrave, R. A. and Musgrave, P. B., 2004. Public finance in theory and practice taxation. McGraw Hill, New Delhi India. 
OECD., 2013. What drives tax morale? Tax and development program, Center for Tax Policy and Administration.

Ojochogwu, W. A. and Ojeka, S. A., 2012. Factors that affects tax compliance among small and medium enterprise (SMEs) in North Central Nigeria: International Journal of Business and Management, 7.

Okonjo-Iweala., 2014. Nigerian tax to GDP ratio of ${ }^{7} \%$ not acceptable. vv $\backslash \mathrm{v} \backslash \mathrm{v}$. the n a t

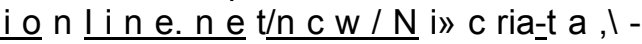
to-adp-ratio-c)!-_?-not-;Kx;.e]21 a b I e

Simser, J., 2008. Tax evasion and avoidance typologies. Journal of Money Laundering V Control, 11(2), 123 - 134.

Tijani, O. M. and Ogundeji, M., 2013. Professional perspective of tax evasion: Some evidence from Nigeria. Universal Journal of Accounting and Finance, 1 (2), $35-41$

Timmon, J. F., 2005. The fiscal contract: state, taxes, and public services. World Policies, 57,530-567.
Umar, M. A., Derashid, C. and Ibrahim, I., 2017. Challenges of tax revenue generation in developing countries: Adopting the carrot and stick approach. Journal of Humanities and social sciences, 22(1), 30-34.

Yahaya, K. A., 2009. An analysis of the challenges of taxation in Kwara State. Liforma 2(2).

Worlu, C. N. and Emeka, N., 2012. Tax revenue and economic development in Nigeria: A macro econometric approach. Academic Journal of Interdisciplinary Studies, 1(2), 214-222. 